\title{
Factors Affecting the Maintenance of Dental and Oral Health in Children of Elementary School of Harapan 1 Class 3 in Sumber Mulyo Rejo District Madya Binjai City
}

\author{
Ana Indrawati, Muhammad Badira', Imam Muhammad ${ }^{1}$ \\ ${ }^{1}$ Faculty of Public Health, Medan Helvetia Health Institute, Indonesia \\ Corresponding Author: Ana Indrawati

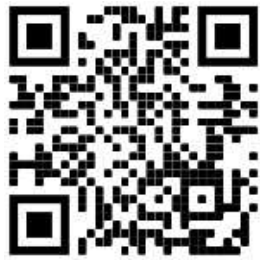

Article Info

Article history:

Received 29 September 2020

Received in revised form 6

October 2020

Accepted 8 October 2020

Keywords:

Caries

Elementary school

Dental

Oral Health
Abstract

This study aims to determine the factors that influence the maintenance of oral health in SD (Elementary School) Harapan 1 grade 3 children in Sumber Mulyo Rejo Village, Binjai Madya City in 2018. The design of this study was an analytical observational study with a cross sectional study type. The research was conducted in SD Harapan I grade 1 to grade 3 in Sumber Mulyo Rejo Village, Binjai Madya City in 2018. When the research was conducted in February-September 2018. The number of samples was 86 respondents and data collection used a questionnaire. Data analysis was performed using univariate, bivariate (chi square) and multivariate (multiple logistic regression prediction models). The results showed that the maintenance of dental and oral health in SD Harapan 1 grade 1 to grade 3 children in Sumber Mulyo Rejo Village, Binjai Madya City in 2018 was $75.6 \%$ not good. There is a significant relationship between student knowledge, student attitudes, diet, motivation to care for teeth, the UKGS program, and the attitudes of parents at SD Harapan I Binjai with the maintenance of dental and oral health for students at SD Harapan I Binjai in 2018. The conclusion of this study is that motivation to care for teeth is a factor that is most related to the maintenance of dental and oral health in SD Harapan 1 grade 1 to grade 3 children in Sumber Mulyo Rejo Village, Binjai Madya City, 2018. Promotional efforts are needed to increase students' knowledge about the importance of maintaining oral health such as posters on how to brush teeth true, good time brushing teeth, toothpaste used for brushing teeth and brushing teeth directly activities together at school.

Introduction

Several studies stated that dental and mouth disease is a behavioral disease or disease related to behavior. The prime degree of dental and oral health is a reflection of the experience of good oral and dental care behavior (Petersen et al., 2005; Peker et al., 2010). Behavior is formed through a series of processes involving several factors. According to Green (1999), a person's behavior is influenced by 3 main factors summarized in the acronym PRECEDE (Predisposing, enabling, and reinforcing). PRECEDE can be used to analyze and evaluate a person's health behavior. These three factors are interrelated to form a person's health behavior.

Oral and dental health is an important part of determining the health status of children, especially school age children. This is because school age is an age that is prone to experiencing oral and dental problems. The occurrence of dental and oral health problems in school-age children can have an impact on the decline in the health status of school-age children. 
According to Wahyuningrum, the behavior of children in maintaining dental and oral hygiene, namely by brushing their teeth regularly and correctly, especially at school-age children, needs special attention because at this age children are undergoing a process of growth and development (Alamsyah, 2010). Personal dental and oral hygiene maintenance activities carried out at home without any supervision from anyone, are entirely dependent on the knowledge, understanding, awareness and willingness of the individual to maintain oral hygiene. (Sumanti et al., 2013).

Tooth and mouth disease in Indonesia is one of the diseases with a high prevalence rate above the national average. Correct behavior in brushing teeth is related to gender, economy and area of residence. Only $2.3 \%$ of Indonesians brush their teeth properly. Based on the level of education, the higher the education, the better the behavior of brushing teeth properly. Likewise, in the area of residence, respondents in urban areas were more likely to brush their teeth correctly than in rural areas, men were $2.0 \%$ lower than women, $2.5 \%$. (Kapti et al., 2013)

According to a study according to Edwina \& Sally (2013) in Spain on students aged 12 years, found that children with better knowledge tended to have better attitudes and behaviors related to dental and oral health care than children with less knowledge, but not significantly different. significant (Sohn \& Rowe, 2015). After multiple regression in the same study, better knowledge levels were significantly associated with positive behavior. The results of this study, found that there was a significant increase in the behavior of mothers under five after being given information through audio-visual media counseling, this is because all media are actually useful to clarify, create a deep impression, meaning that what is being conveyed is not easily forgotten by respondents.

From the results of the preliminary survey data conducted at the Binjai City Health Center, it was found that $42 \%$ of children suffered from cavities. At Elementary School (SD) Harapan 1 Kelurahan Sumber Mulyo Rejo, Binjai Madya City, out of 10 students whose teeth were examined, it was found that 8 students had oral health problems which were marked by bad breath, blackish teeth, dental plaque and cavities found. . Cavities are the most common disease in children and can occur due to bad oral health care behavior. One of the goals of health development in Indonesia is efforts to improve health, including oral health. What can be done to achieve this goal is to carry out preventive activities to prevent the occurrence of oral diseases at an early age. These preventive activities include providing counseling on the proper and correct way and frequency of brushing teeth, routine check-ups to the dentist every 6 months, improving oral health programs at regional health centers, and improving the factors that affect dental and oral care behavior. .

The factors that influence oral health care behavior are not widely known, so it is necessary to conduct research to see the factors that influence the maintenance of oral health in SD Harapan 1 grade 3 children in Sumber Mulyo Rejo Village, Binjai Madya City in 2018.

\section{Methods}

The design of this study was an analytic observational study with a cross sectional study type. The research was conducted in SD Harapan I grade 1 to grade 3 in Sumber Mulyo Rejo Village, Binjai Madya City in 2018. When the research was conducted in February-September 2018. The number of samples was 86 respondents and data collection used a questionnaire. Data analysis was performed using univariate, bivariate (chi square) and multivariate (multiple logistic regression prediction models). 
Table 1. Multiple Logistic Regression Analysis Prediction Model of Dental and Oral Health Maintenance of SD Harapan I Binjai Elementary School Children in 2018

\begin{tabular}{rlccccc}
\hline No & Variabel & B & Std.Eror & df & Sig & Exp (B) \\
\hline 1 & Attitude of students & 0,224 & 0,574 & 1 & 0,046 & 0,799 \\
2 & Diet & 0,278 & 1,275 & 1 & 0,027 & 0,757 \\
3 & Motivation for caring for & 0,933 & 1,165 & 1 & 0,023 & 2,541 \\
4 & UKGS program & 0,997 & 1,098 & 1 & 0,024 & 2,110 \\
5 & Attitude of parents & 0,256 & 0,629 & 1 & 0,054 & 1,292 \\
6 & Constant & 0,653 & 2,200 & 1 & 0,017 & 0,520 \\
\hline
\end{tabular}

The study succeeded in collecting data on the characteristics of respondents based on the gender of Elementary School (SD) Harapan I Binjai. Characteristics of respondents at SD Harapan I Binjai based on gender were dominated by women $(54.7 \%)$ or about 47 people and male as many as 39 people or $45.3 \%$.

Age is very influential on a person's knowledge because age affects one's comprehension and mindset. In children, there will be similarities with their parents, this is called the identification process. At this time, the parents need to be firm in familiarizing their children with positive activities. At this age is the best time to start using a toothbrush. Starting from the age of 2, children can be taught to brush their teeth using the simplest method. $(7,14)$ The average knowledge of students about the maintenance of oral health was not good, namely $51.2 \%$ or as many as 44 students and 44 students also had negative attitudes towards maintaining oral health. As many as 82 students or $95.3 \%$ on average consumed a diet that triggered dental caries every day. In terms of motivation, as many as 78 students had good motivation to maintain oral health $(90.7 \%)$. The UKGS program has been running well at SD Harapan I Binjai, which is $89.5 \%$ and the knowledge of parents about maintaining oral health is also good, namely $89.5 \%$ but $69.8 \%$ of students' parents/guardians still have negative attitudes towards maintenance of oral health. Education is any effort that is planned to influence other people, be they individuals, groups or communities so that they do what is expected by the actors of education. (Pitriyanti \& Septarini, 2016).

The habit of Indonesian people in brushing their teeth is still not good. Based on Rahim's observations, it turns out that irregular brushing habits have a significant effect on the incidence of dental caries and good tooth brushing habits can indeed help prevent dental caries because teeth become clean from food debris, bacteria, and plaque that damage teeth. Teeth should be brushed after eating, and before going to bed. At night, especially during bedtime, the amount of human saliva tends to decrease, as a result the mouth becomes dry and the plaque neutralization process does not take place optimally, and can cause dental caries. (Nirham et al., 2014).

The results of the 2016 Pay study in Budisuari et al., (2010) show that motivation contributes $40.0 \%(\mathrm{R} 2=0.400)$ to children's behavior in maintaining dental and oral hygiene. Motivation has the greatest influence, namely $10.4 \%$ on children's behavior in maintaining oral and dental hygiene. The better the perception and the stronger the motivation, the better the child's behavior in maintaining dental and oral hygiene. Attitudes do not affect children's behavior in maintaining oral and dental hygiene. Motivation has the greatest influence on children's behavior in maintaining oral and dental hygiene.

The School Dental Health Business (UKGS) is an integral part of the School Health Business (UKS) which carries out planned dental and oral health services to students, especially Elementary School (STD) students within a certain period of time and is carried out continuously through the UKS package, namely minimum package, standard package and 
optimal package. UKGS is the main means of improving the dental and oral health of school children. Through the UKGS, a good attitude towards dental and oral health can be instilled through health education and counseling activities carried out as well as existing actions and treatments. (Ningsih et al., 2016).

Usually, the average length of time to brush your teeth is approximately 1 minute. The duration of a person brushing teeth is recommended to be minimal

5 minutes, but generally people brush their teeth a maximum of 2-3 minutes. This timing is not the same for everyone, especially in people who really need plaque control. If brushing is done in a short time, the results are not so good than if brushing is done for a longer time, considering the large number of tooth surfaces that must be cleaned (Windarti, 2016).

Parents' knowledge and concern for children's dental health influences the behavior of maintaining oral health in children. Parents with low knowledge of dental and oral health are a predisposing factor for behavior that does not support children's oral and dental health, but many parents think that deciduous teeth are less important, because they are temporary and will be replaced by permanent teeth which in normal circumstances will last forever. in the oral cavity. This assumption is certainly very wrong considering the role and function of deciduous teeth. It is in this dental period that children should begin to be taught and motivated to keep their teeth clean and healthy (Budisuari et al., 2010).

\section{Conclusion}

The factors most related to the maintenance of dental and oral health in SD Harapan 1 grade 1 to grade 3 children in Sumber Mulyo Rejo Village, Binjai Madya City, 2018. Promotional efforts are needed to increase students' knowledge about the importance of maintaining oral health, such as posters on how to brush correct teeth, good time brushing teeth, toothpaste used for brushing teeth and brushing teeth together at school.

\section{References}

Alamsyah, R. M. (2010). Need Pemeriksaan dan Perawatan Gigi Pada Ibu-Ibu Di Kelurahan Sari Rejo Kecamatan Medan Polonia Kotamadya Medan Tahun 2009. Thesis, Universitas Sumatera Utara.

Budisuari, M. A., Oktarina, O., \& Mikrajab, M. A. (2010). Hubungan pola makan dan kebiasaan menyikat gigi dengan kesehatan gigi dan mulut (karies) di Indonesia. Buletin Penelitian Sistem Kesehatan, 13(1), 21306.

Budisuari, M. A., Oktarina, O., \& Mikrajab, M. A. (2010). Hubungan pola makan dan kebiasaan menyikat gigi dengan kesehatan gigi dan mulut (karies) di Indonesia. Buletin Penelitian Sistem Kesehatan, 13(1), 21306.

Edwina, S. J., \& Sally, J. (2013). Dasar-dasar Karies Penyakit dan Penanggulangan. Jakarta: EGC.

Green, L., \& Kreuter, M. (1999). The precede-proceed model. Health promotion planning: an educational approach. 3rd ed. Mountain View (CA): Mayfield Publishing Company, 32-43.

Kapti, R. E., Rustina, Y., \& Widyatuti, W. (2013). Efektifitas audiovisual sebagai media penyuluhan kesehatan terhadap peningkatan pengetahuan dan sikap ibu dalam tatalaksana balita dengan diare di dua rumah sakit kota Malang. Jurnal Ilmu Keperawatan: Journal of Nursing Science, 1(1), 53-60. 
Ningsih, S. U., Restuastuti, T., \& Endriani, R. (2016). Gambaran Pengetahuan dan Sikap Menyikat Gigi pada Siswa-siswi dalam Mencegah Karies di Sdn 005 Bukit Kapur Dumai. Thesis, Riau University.

Nirham, A., Nursalim, D. S., \& Darmawan, S. (2014). Faktor-faktor yang mempengaruhi kejadian karies gigi pada siswa kelas 1 di SD Negeri 1 Pekkae Kecamatan Tanete Rilau Kabupaten Barru. Jurnal Ilmiah Kesehatan Diagnosis, 4, 414-415.

Peker, K., Uysal, Ö., \& Bermek, G. (2010). Dental training and changes in oral health attitudes and behaviors in Istanbul dental students. Journal of dental education, 74(9), 10171023.

Petersen, P. E., Bourgeois, D., Ogawa, H., Estupinan-Day, S., \& Ndiaye, C. (2005). The global burden of oral diseases and risks to oral health. Bulletin of the World Health Organization, 83, 661-669.

Pitriyanti, L., \& Septarini, N. W. (2016). Determinan Karies Gigi Pada Anak Sekolah Dasar Di Pulau Nusa Penida, Klungkung, Bali. VIRGIN: Jurnal Ilmiah Kesehatan Dan Sains, 2(1).

Sohn, H. A., \& Rowe, D. J. (2015). Oral health knowledge, attitudes and behaviors of parents of children with diabetes compared to those of parents of children without diabetes. American Dental Hygienists' Association, 89(3), 170-179.

Sumanti, V., Widarsa, T., \& Duarsa, D. P. (2013). Factors related to parent's participation in child dental health care in Tegallalang I community health centre. Public Health and Preventive Medicine Archive, 48.

Windarti, N. (2016). Hubungan Perilaku Menggosok Gigi Dengan Kejadian Karies Gigi Pada Anak Usia 6-12 Tahun Di Sd Negeri 1 Tamanwinangun Kebumen Tahun 2016. Thesis, Stikes Muhammadiyah Gombong. 